INTERNATIONAL JOURNAL OF

MULTIDISCIPLINARY STUDIES ON MANAGEMENT, BUSINESS, AND ECONOMY

ISSN: $2735-5446$

VOLUME 1, ISSUE 2, 2018, 8- 10 .

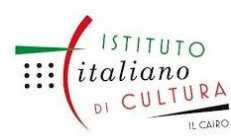

www.egyptfuture.org/ojs/

\title{
THE ROLE OF INDUSTRIAL CLUSTERS IN RAISING THE EFFICIENCY OF GARMENT INDUSTRY'S SMALL ENTERPRISES
}

\author{
Muhammad Farouk Aidarous Muhammad *
}

BSC in Home Economics

\begin{abstract}
As the international experiences of many small industrial projects pointed to the problems that led to the failure of these projects, especially in the field of ready-made garments, to achieve savings in the volume of materials when purchasing materials necessary for production such as raw materials and equipment, in addition to the problems of poor financing and consulting services, which prevents These projects achieve marketing opportunities that require mass production, homogeneous standards and regular supply. (Lubna Abd al-Latif: 2003).Given that these projects operate separately and separately, this leads to exposure to many obstacles that affect the performance of the facility, and since convergence and cooperation between small industrial enterprises is the main factor in overcoming and facing these obstacles, and it also contributes to improving the competitive position of these projects, This led to the emergence of what are known as "industrial clusters, known as geographical groupings of a number of companies and institutions linked to each other in a specific field, representing an integrated system of industries and complementary industries such as buttons, zippers, packaging, padding, ticks and other auxiliary entities such as embroidery."
\end{abstract}

Keywords

INDUSTRIAL CLUSTERS- GARMENT INDUSTRY'S- SMALL ENTERPRISES.

\section{Introduction}

Small industrial enterprises in the ready-made garment industry play an important role in achieving economic growth and development in developing countries, as these projects contribute to generating employment, reducing poverty rates, and achieving a fair and broad distribution of wealth and economic opportunities, but there are some problems facing these projects that prevent them from achieving These projects have their desired goals. (Mustafa Abdel Salam: 2007)

As the international experiences of many small industrial projects pointed to the problems that led to the failure of these projects, especially in the field of ready-made garments, to achieve savings in the volume of materials when purchasing materials necessary for production such as raw materials and equipment, in addition to the problems of poor financing and consulting services, which prevents These projects achieve marketing opportunities that require mass production, homogeneous standards and regular supply. (Lubna Abd al-Latif: 2003)

Given that these projects operate separately and separately, this leads to exposure to many obstacles that affect the performance of the facility, and since convergence and cooperation between small industrial enterprises is the main factor in overcoming and facing these obstacles, and it also contributes to improving the competitive position of these projects, This led to the emergence of what are known as "industrial clusters, known as geographical groupings of a number of companies and institutions linked to each other in a specific field, representing an integrated system of industries and complementary industries such as buttons, zippers, packaging, padding, ticks and other auxiliary entities such as embroidery."

And printing to encourage and support competitiveness. The industrial cluster represents the integrated chain, as it includes most of the stages of the production process through which many advantages and problems facing small industrial enterprises can be achieved. (Aboud Zarkin: 2014)

This called for the current research to attempt to develop a proposed model for industrial clusters through which development and advancement of small enterprises in the field of ready-to-wear garments could be achieved.

The research problem can be formulated in the following questions:

1- What is the role that industrial clusters can play in the readymade garment industry? 2- What is the possibility of developing a proposed model for industrial clusters for small projects in the field of ready-made

* Corresponding author: author@institute.xxx 


\section{THE ROLE OF INDUSTRIAL CLUSTERS IN RAISING THE EFFICIENCY OF GARMENT INDUSTRY'S SMALL ENTERPRISES}

clothes? 3- What is the opinion of the experts on the proposed model for the industrial cluster in the readymade garment industry?

research importance

The importance of the research is evident in that it deals with one of the important sectors that make up the industrial sector, which is the ready-made garment industry, which is one of the industries that support the national economy, due to its absorption of a large number of workers in all sectors related to the spinning, textile and clothing industry.

The importance of the research is also due to the fact that it addresses one of the obstacles facing small industries in the ready-made garment industry and contributes to providing solutions to reduce them, which is in line with the current policy of the state, which calls for support for small industries, and in response to the recommendations prepared by the Central Bank 2015.

In addition, the results of the research can contribute to providing solutions through which small enterprises in the field of ready-to-wear can be promoted.

Research goal:

1- Determine the role that industrial clusters play in the field of manufacturing ready-made clothes.

2- Designing a proposed model for industrial clusters in the readymade garment industry.

3- To know the opinion of experts on the proposed model for industrial clusters for the manufacture of ready-made clothes.

\section{Search limits}

This research is limited to examples of small enterprises in the field of ready-to-wear clothing industry in the Arab Republic of Egypt, and what the industrial clusters are.

\section{Research sample:}

The research sample consisted of two groups as follows:

First - (10) vocabulary for owners of small factories) visited to learn about the nature and components of small enterprises in them. Second - (25) experts to evaluate a proposed model for industrial clusters in the garment industry.

\section{Search tools}

1- An open questionnaire to collect information and data related to the shape and nature of the industrial cluster in the field of ready-made clothes.

2- A questionnaire form determining the role of industrial clusters in the field of ready-made clothes.

3- A form for assessing the level of competency of a proposed model for industrial clusters in the field of ready-to-wear garments.

\section{Research hypotheses}

1- The role of industrial clusters in the field of ready-made garments does not differ according to the axes (achieving quality, integration between industries, flexibility in production and finally economic growth) from the point of view of experts in the field.

2- A proposed model can be designed for industrial clusters in the field of ready-made clothes.

3- The opinions of experts towards the proposed model for industrial clusters in the field of ready-made clothes are positive. Of the total number of grades, it reached (1) expert, at a rate of $4 \%$, and the number of experts for the higher quarter, i.e. those who obtained $75 \%$ of the total number of grades or higher, reached (24) expert with a rate of $96 \%$. This is consistent with the results of the study (Reza Bahjat Amin: 2010) "as well as the results of the study (Iman El-Sherbiny: 2008), where it was agreed that developing models for industrial clusters for the advancement of small enterprises helps to specialize each unit of the cluster.

The industrial sector is at a specific stage of production, which supports the competitiveness of the industry as a whole as well as enables it to raise the productive and competitive capabilities of all units included in the cluster exports. It is also one of the most important methods of increasing exports, reducing unemployment rates and raising the overall growth rates. The proposed model for industrial clusters in the readymade garment industry. Thus, the third hypothesis is validated.

\section{Research recommendations}

The results of this research indicated that there are many types of small enterprises in the field of the ready-made garment industry. They also indicated that the role of industrial clusters in the field of the ready-made garment industry does not differ according to the axes (achieving quality, integration between industries, flexibility in production, and economic growth) from the point of view. Experts looked at the field, and it also indicated the possibility of developing a proposed model for industrial clusters in the field of ready-made clothes, and indicated that the opinions of experts towards the proposed model are positive, and in light of the results of the current study, the researcher recommends the following:

1- Addressing the ready-made clothes room in the Federation of Industries to adopt the proposed model in the field of ready-made clothes. 
2- Urging researchers in the clothing industry to conduct more studies related to industrial clusters. to promote it.

3- Directing those in charge of the ready-made garment industry to activate the industrial clusters system

4- Addressing the concerned authorities in the government to define a geographical map showing the areas that have a comparative advantage or connection with the environment and the resources available to establish small projects in the field of ready-made garments, and try to link them together by adopting the idea of industrial clusters.

\section{References}

$$
\begin{aligned}
& \text { ـ البنك المركزى المصرى (2015) : نشرة دورية ربع سنوية ، تقرير منشور ، المجلة الاقتصادية . }
\end{aligned}
$$

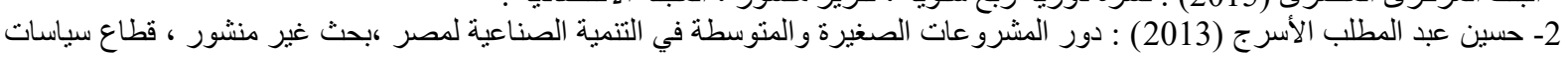

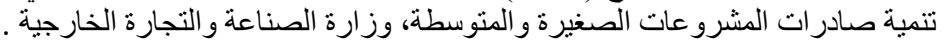

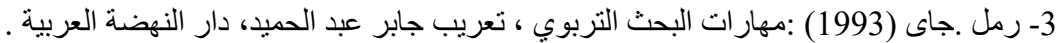

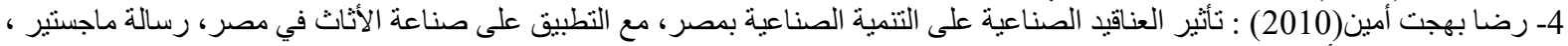

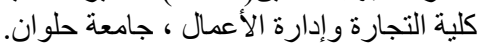

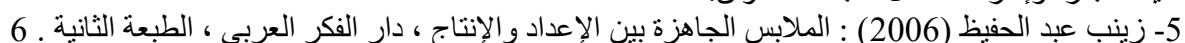

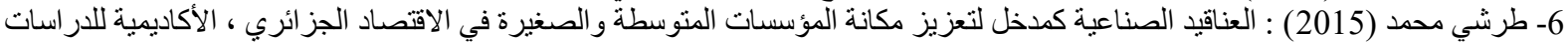

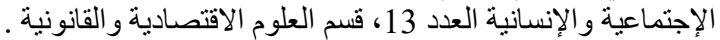

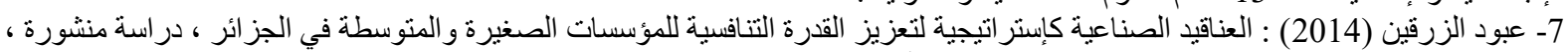

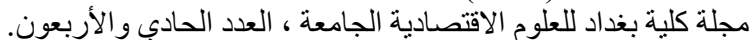

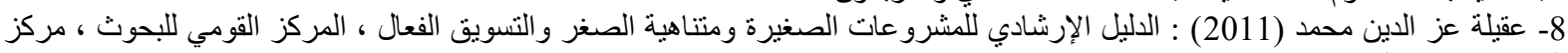

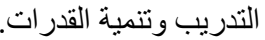

$$
\begin{aligned}
& \text { 9- لبنى عبد اللطيف (2003) : العناقيد الصناعية كاستر اتيجية لتنمية المشرو عات الصغيرة ومنوسطة الحجم ،دراسة منشورة ، مركز المعلومات }
\end{aligned}
$$

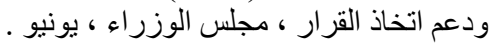

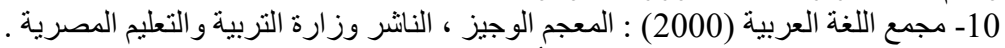

13- Banji Oyelaran-Oyeyinka and Dorothy McCormick (2007) : Industrial clusters and innovation systems in Africa, Institutions, markets and policy, United Nations University.

14- Bob Lowson (2006) : Quick Response for Small and Medium-sized Enterprises - A Feasibility Study (University of Wales, Cardiff, The Textile Institute .

15- Eric A. Scorsone (2005): Industrial clusters: Enhancing rural economies, through business linkages , University of Kentucky.

16- Thomas Brenner (2004): Local lindustrial Cluster Existence, Emergence and Evolution , Simultaneously Published in the USA.

Received: February 15, 2018

Accepted: April 20, 2018 